JURNAL RESPIRASI
JR

Vol. 4 No. 3 September 2018

\title{
Pneumotoraks Bilateral dan Transaminitis Non Spesifik pada Silikosis
}

\author{
Sahrun*, Winariani Koesoemoprodjo, Ariani Permatasari \\ Departemen Pulmonologi dan Ilmu Kedokteran Respirasi, Fakultas Kedokteran, Universitas Airlangga/RSUD Dr. Soetomo
}

\begin{abstract}
Background: Silicosis is a fibrosis in the lung caused by inhalation, retention, and reaction to crystalline silica. The prevalence rate is potentially increasing throughout the world. Cases of bilateral spontaneous pneumothorax and transaminitis due to complications of silicosis are very rare. In this case, the patient was presented with bilateral secondary spontaneous pneumothorax as well as in the development of the diagnosis of silicosis, liver dysfunction, and pneumonia. Case: A 36-year-old male was admited to hospital with shortness of breath, the patient was once stone artisans for 7 years, rarely using PPE. Bilateral pneumothorax was established based on the results of clinical and radiological examinations. HRCT showed that it supported silicosis, left fluidopneumothorax, and right pneumothorax. Bronchoscopy was not possible due to the incompatible conditions and subsequently the patient was examined for silica levels from both plueral fluid with significant pleural silica. Summary: Diagnosis of pulmonary silicosis was done by clinical, radiological, and silica analysis of bronchial rinses, but certain conditions of silica could be found from pleural fluid. Silicosis therapy with complications until recently is only symptomatic, definitive therapy has not been found. Silicosis complications can be from pneumothorax bilateral (rarely), tuberculosis, transaminitis, and pneumonia. Conclusion: Pulmonary silicosis can be found from pleural fluid when the amount is large enough, fibrosis and extensive lung damage occurred. Silicosis can have an impact on pneumothorax, liver disorders, pneumonia, tuberculosis, and respiratory problems.
\end{abstract}

Keywords: silicosis, pneumothorax, transaminitis, bronchoscopy

Correspondence: Sahrun, Departemen Pulmonologi dan Ilmu Kedokteran Respirasi, Fakultas Kedokteran, Universitas Airlangga/RSUD Dr. Soetomo. J1. Mayjen Prof. Dr. Moestopo 6-8 Surabaya 60286. E-mail: cahrun.carter@gmail.com

\section{PENDAHULUAN}

Penyakit paru kerja adalah penyakit yang paling banyak dijumpai di antara semua penyakit akibat kerja. Hal ini disebabkan rata-rata waktu yang dihabiskan di tempat kerja $\pm 8 \mathrm{jam} / \mathrm{hari}$, di mana terhirup $\pm 3500 \mathrm{~L}$ udara termasuk partikel debu atau bahan pencemar lain yang terdapat di dalamnya. Partikel debu lingkungan kerja dibagi menjadi debu organik (nabati, hewani), debu inorganic (pertambangan, industri logam, keramik), dan gas iritan (industri petrokimia, farmasi). ${ }^{1}$

Silika dan silikon dioksid merupakan komponen yang berasal dari lapisan kulit bumi. Ketika banyak digunakan di bidang industri, bahan tersebut menjadi bahan yang potensial menyebabkan penyakit paru kerja. Tempat kerja dengan risiko terkena silikosis antara lain: pertambangan emas, besi, timah, granit, pasir, batu tulis, pengecoran logam, pabrik semen, keramik dan gelas. ${ }^{2}, 3$
Silikosis merupakan penyakit fibrosis pada paru yang disebabkan oleh inhalasi, retensi, dan reaksi terhadap silika kristalin. Angka prevalensinya potensial meningkat di seluruh dunia. Karena silika sangat murah dan merupakan komponen yang serba guna, maka banyak digunakan di sektor industri dunia dan jutaan pekerja berkecimpung di dalamnya. ${ }^{4}$

Berdasarkan data NIOSH (National Institute of Occupational Safety and Health) di Amerika Serikat, sekitar 1,7 juta pekerja terpajan silika dengan rata-rata 1.500 sampai 2.360 orang yang menderita silikosis setiap tahunnya. ${ }^{2}$ Studi surveilans yang dilakukan di Michigan, Amerika Serikat, antara tahun 1987 hingga 1995 menunjukkan bahwa sebanyak lebih dari 60\% pekerja pabrik/pertambangan yang telah bekerja selama minimal 20 tahun, sebanyak 577 pekerja, menderita silikosis. Tahun 1996 silikosis dilaporkan terjadi pada 60 orang dari 1.072 pekerja pabrik mobil. $^{2}$ 
Studi epidemiologi abad ke-20 menunjukkan adanya hubungan antara silikosis dengan tuberkulosis (TB) paru. Risiko silikosis berkembang menjadi TB paru adalah sebesar 2,8 sampai 39 kali lebih tinggi daripada pasien tanpa silikosis, karena peningkatan kerentanan penderita silikosis terhadap TB. ${ }^{3}$

Silikosis akut dan silikosis terakselerasi adalah bentuk silikosis yang memiliki insidens tertinggi dalam hubungannya dengan TB. Diagnosis silikotuberkulosis rata-rata 7,6 tahun setelah pajanan silikosis berakhir. Dalam tiga dari empat penelitian, terjadinya TB berhubungan langsung dengan jumlah kumulatif pajanan, serta lamanya waktu bekerja di pertambangan. ${ }^{4}$ Transport partikel silika yang terhirup atau termakan dapat menyebar secara sistemik. Efek sistemik silika adalah silikosis hepatik dan/atau hepatosplenik silikosis, granuloma hepatosplenik silikosis, porfiria hepatik, granuloma cutaneous silika, dan abrasi gusi. Komplikasi lain dari silikosis adalah pneumotoraks spontan sekunder. Pneumotoraks spontan sekunder sering berhubungan dengan silikosis kronis dan silikosis terakselerasi dengan fibrosis masif progresif. Kasus pneumotoraks spontan sekunder sering terjadi unilateral, sangat jarang terjadi bilateral. ${ }^{5}$ Gejala klinis silikosis pada stadium awal biasanya tidak memberikan gejala yang spesifik, sehingga biasanya pasien baru datang dengan komplikasi berupa sesak napas. Pada kasus ini pasien datang dengan keluhan sesak napas disertai pneumotoraks spontan sekunder bilateral serta dalam perkembangan evaluasi juga mengalami gangguan fungsi hati yang mana komplikasi seperti ini sangat jarang terjadi.

\section{KASUS}

Seorang pasien masuk rumah sakit (RS) dengan keluhan sesak napas sejak 2 bulan dan memberat sejak 5 hari. Batuk sejak 3 tahun yang semakin memberat 2 minggu terakhir, batuk disertai dahak warna kuning, nyeri dada kanan dan kiri yang memberat saat aktifitas berat, panas naik turun sejak 5 hari, nafsu makan menurun, keringat malam disangkal, berat badan menurun.

Pasien pernah memeriksakan diri ke spesialis penyakit dalam dan dikatakan paru-parunya terdapat flek dan kempes, disarankan untuk rawat inap di RS dan dilakukan pemasangan selang dada, namun pasien menolak karena trauma banyak rekannya dengan sakit yang sama meninggal. Pasien akhirnya hanya mendapat obat batuk dan antibiotik selama 4 bulan. Pasien dirawat di RS Nganjuk selama 3 hari sebelum dirujuk ke RS Dr. Soetomo dan mendapatkan pengobatan injeksi ranitidin, santagesik, diphendhidramin, ciprofloxacin, combivent nebulizer, ambroxol tablet. Riwayat asma, TB, batuk dan sesak berulang, hipertensi, dan penyakit jantung disangkal.

Pasien bekerja sebagai pengrajin marmer, bagian pengasah dan pembuat marmer dari bahan batu kali. Pasien bekerja selama 7 tahun, setiap Senin-Jumat pukul 08.00-15.30, kadang disertai lembur. Pada saat bekerja pasien tidak rutin memakai alat pelindung seperti masker, masker mulai disadari untuk dipakai rutin sejak 3 tahun terakhir. Masker yang dipakai adalah masker kain yang bisa dipakai hingga 3 hari diganti/dicuci, masker tersebut khusus dipakai saat kerja. Debu batu kali biasanya terhirup terutama saat pasien mengasah atau gerinda batu kali untuk dibentuk menjadi kerajinan seperti wastafel, suvenir, perlengkapan rumah tangga, dsb. Pasien bekerja di dalam ruangan berbatas tembok dan beratap dengan ventilasi cukup. Pasien tergolong pekerja keras, punya skill tinggi dan sering diberikan porsi kerja lebih dibanding lainnya. Selain pasien, rekan kerja pasien di tempat yang sama juga menderita sakit yang sama dengan pasien dan telah dinyatakan meninggal sebanyak 7 orang setelah sebelumnya menjalani perawatan pemasangan selang dada. Selain di tempat kerja pasien, kelompok kerja batu asah di kawasan tempat tersebut dikabarkan sudah banyak yang menderita penyakit saluran napas dan dikabarkan tiap tahun selalu ada yang meninggal. Pasien sudah menikah dan memiliki 1 orang anak. Pasien tinggal serumah dengan anak dan istrinya. Pasien tidak memiliki

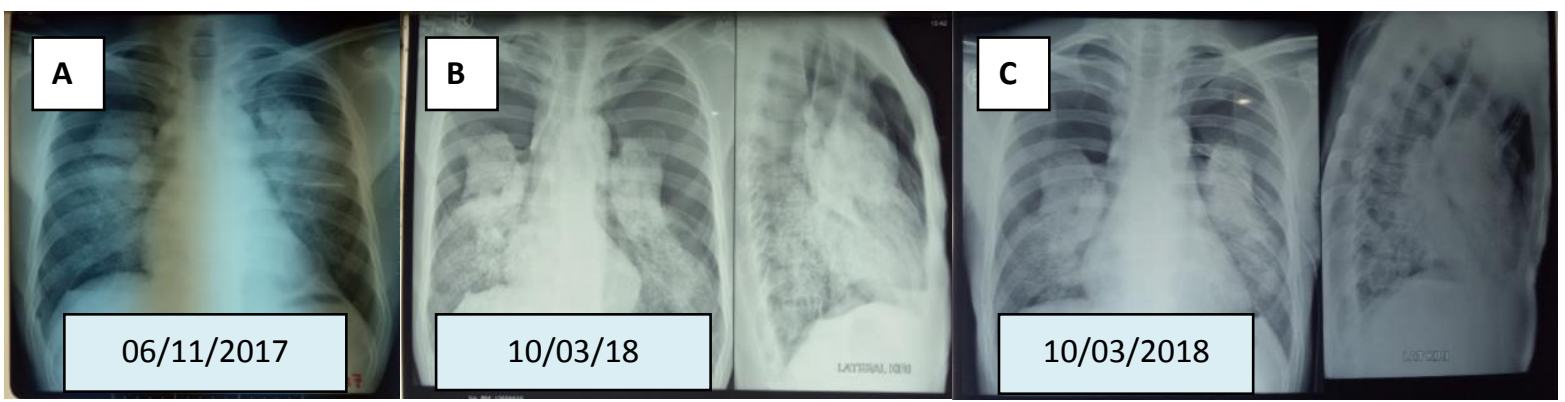

Gambar 1 A. Foto toraks pasien saat pertama kali melakukan pemeriksaan ke dokter spesialis penyakit dalam. Tampak adanya garis kolaps di kedua lapang paru dan mendesak jaringan paru ke sentral hingga 50\%.

B. Foto toraks pasien saat masuk IGD RS Dr. Soetomo, tampak adanya garis kolaps di kedua hemitoraks dan kedua paru terdesak ke sentral.

C. Foto toraks pasien setelah pemasangan chest tube sinistra, dibandingkan foto toraks sebelum pemasangan paru kiri sedikit mulai mengembang, namun belum sempurna. 
riwayat konsumsi alkohol, maupun obat terlarang.

Keadaan umum pasien lemah, BMI terkategori underweight dengan nilai $17,63 \mathrm{~kg} / \mathrm{m}^{3}$. Kesadaran kompos mentis, tekanan darah $130 / 80 \mathrm{mmHg}$, nadi $110 \mathrm{x} /$ menit, frekuensi napas $36 \mathrm{x} /$ menit, suhu aksiler $36,6^{\circ} \mathrm{C}$, saturasi oksigen $\left(\mathrm{O}_{2}\right) 96 \%$ dengan $\mathrm{O}_{2}$ simple mask $6 \mathrm{~L} /$ menit.

Pada regio toraks inspeksi tampak asimetris kiri tertinggal, fremitus raba menurun pada $2 / 3$ atas hemitoraks kanan dan kiri, hipersonor $2 / 3$ atas lapang paru kanan dan kiri, suara napas vesikuler menurun pada 2/3 atas hemitoraks kanan dan kiri. Analisa gas darah (AGD) dengan oksigen simple mask ( $\mathrm{pH} 7,39, \mathrm{pCO}_{2} 51$ $\mathrm{mmHg}, \mathrm{pO}_{2} 79 \mathrm{mmHg}, \mathrm{HCO}_{3} 30,9 \mathrm{mmol} / \mathrm{l}, \mathrm{TCO}_{2} 32,5$ $\mathrm{mmol} / \mathrm{l}, \mathrm{BE} \mathrm{5,9} \mathrm{mmol} / \mathrm{l}, \mathrm{SO}_{2} 95 \%, \mathrm{AaDO}_{2} 7 \mathrm{mmHg}$ ) didapatkan alkalosis respiratorik dengan hipoksemia sedang.

Evaluasi pada tanggal 14 Maret 2018 pasien merasakan sesak semakin berat, nyeri dada kanan dan kiri menetap, serta batuk tanpa dahak. Pemeriksaan laboratorium didapatkan peningkatan Serum Glutamic Oxaloacetic Transaminase (SGOT), Serum Glutamic Pyruvic Transaminase (SGPT) 73/160 U/L, leukositosis $14.200 / \mathrm{mm}^{3}$, analisa gas darah didapatkan $(\mathrm{pH} \mathrm{7,4,}$ $\mathrm{pCO}_{2} 51 \mathrm{mmHg}, \mathrm{pO}_{2} 56 \mathrm{mmHg}, \mathrm{TCO}_{2} 33 \mathrm{mmol} / 1,2, \mathrm{BE}$ $6,8 \mathrm{mmol} / 1, \mathrm{SO}_{2} 89 \%, \mathrm{AaDO}_{2} 116 \mathrm{mmHg}, \% \mathrm{FIO}_{2} 33 \%$, $\mathrm{HCO}_{3} \quad 31,6 \mathrm{mmol} / \mathrm{l}$ ) asidosis respiratorik kompensasi sebagian alkalosis metabolik dengan hipoksemia berat. Terkait kondisi pasien yang semakin berat maka diputuskan untuk dipasang chest tube kedua pada sisi kanan. Hasil foto toraks (Gambar 2a) tampak sama saat masuk IGD dengan kedua paru masih kolaps, dan tampak adanya penambahan efusi sisi kiri, serta chest tube baru pada sisi kanan.

Pasien diberikan tambahan terapi antibiotik ceftriakson 1 gram tiap 12 jam intravena, curcuma tablet tiap 8 jam, pemasangan chest tube dengan WSD sisi kanan dan kiri disertai suction aktif $-40 \mathrm{mmH}_{2} \mathrm{O}$. Pasien selanjutnya direncanakan pemeriksaan FOB, High Resolution Computed Tomography (HRCT) toraks, dan evaluasi serum elektrolit.

Evaluasi pada tanggal 20 Maret 2018 kondisi pasien semakin memburuk dengan sesak semakin memberat, batuk dengan dahak kering, panas, serta nyeri dada. Pemeriksaan fisik didapatkan fremitus raba turun, hipersonor, suara napas turun pada 2/3 atas lapang paru kanan dan kiri, namun suara napas mulai terdengar di 1/3 bawah paru kanan dan kiri. Hasil laboratorium didapatkan leukosit masih tinggi $10,98 / \mathrm{mm}^{3}$, neutrophil 81,9\%, SGOT/SGPT (367/703) U/L, kalium membaik menjadi 3,9 mmol/L. Hasil pemeriksaan smear sputum gram ditemukan bentukan kuman normal respiratory flora +2 batang gram negatif, dengan background PMN 1+. Kultur dan sensitifitas sputum aerob didapatkan Streptococcus viridans, bakteri yang terisolasi merupakan normal flora saluran pernapasan sehingga tidak dilakukan uji sensitifitas. Hasil AGD didapatkan $\left(\mathrm{pH} 7,30, \mathrm{pCO}_{2} 64 \mathrm{mmHg}, \mathrm{pO}_{2} 74 \mathrm{mmHg}, \mathrm{HCO}_{3} 33\right.$ mmol/l, $\mathrm{AaDO}_{2} 16 \mathrm{mmHg}, \mathrm{BE} 6,9 \mathrm{mmol} / \mathrm{l}$ ) asidosis respiratorik kombinasi asidosis metabolik dengan hipoksemia berat. Hasil foto toraks evaluasi didapatkan pengembangan 1/3 bawah paru kanan dan kiri, nampak infiltrat kanan bawah, serta efusi pleura minimal kiri bawah. Hasil HRCT toraks tanpa kontras: reticullar pattern dengan konsolidasi di kedua lapang paru disertai kalsifikasi minimal di daerah hilar kanan dan kalsifikasi limfonodi masih mungkin gambaran silikosis, fluidopneumotoraks kiri dan pneumotoraks kanan, limfonodi subcentimeter di upper paratrakea kiri.

Pasien didiagnosis sesak napas, gagal napas tipe II, fluidopneumotoraks sinistra, pneumotoraks spontan sekunder dekstra, suspek silikosis, suspek TB, Hospitalized Acquired Pnemumonia (HAP), hipokalemia membaik, transaminitis non spesifik. Pasien diberikan perubahan antibiotik menjadi sefoperazon-sulbactam 2 gram tiap 12 jam intravena dan direncanakan FOB jika kondisi stabil, GeneXpert dahak, LFT serial tiap 3 hari, trial klem WSD 24 jam sisi kanan untuk mengetahui adanya risiko bronkopleural fistel, namun pasien merasa sesak dan nyeri dada hebat, sehingga klem kembali dibuka.

Evaluasi pasien tanggal 26 Maret 2018 kondisi pasien masih sesak, panas, dan nafsu makan menurun. Saat ini pasien dengan penambahan edema pada kedua tungkai dan redup pada 1/3 bawah paru kiri bertambah. Hasil pemeriksaan LFT serial terdapat peningkatan SGOT/SGPT (322/589) U/L, penurunan albumin 2,7 $\mathrm{gr} / \mathrm{dl}$, leukosit $9,82 / \mathrm{mm}^{3}$. Hasil pemeriksaan smear sputum BTA tidak ditemukan bentukan kuman batang tahan asam, GeneXpert sputum hasilnya MTB not detected, Kultur dan sensitifitas sputum aerob didapatkan Escheria coli (ESBL+) sensitif terhadap amikasin, gentamisin, sefoperazone-sulbactam, chloramphenicol, cotrimoxa-zole, meropenem. Hasil evaluasi foto toraks nampak paru kanan semakin mengembang, terdapat penambahan efusi pleura sisi kiri serta opasitas paru kanan dan kiri nampak jelas.

Pasien didiagnosis dengan sesak napas, gagal napas tipe II, pneumotoraks spontan sekunder dekstra, fluidopneumotoraks sinistra, suspek silikosis, TB terkonfirmasi klinis, HAP, hipokalemia membaik, hipoalbumin, transaminitis non spesifik. Pasien diberikan adjuvant OAT karena kecurigaan TB secara klinis dengan regimen SLE (streptomisin $750 \mathrm{mg}$ intramuskular, levofloxacin $750 \mathrm{mg}$ intravena, etambutol $750 \mathrm{mg}$ per oral), sistenol 1 tablet tiap 8 jam, albumin 20\% $100 \mathrm{ml}$ dalam 4 jam.

Pada tanggal 4 April 2018 kondisi pasien membaik, meskipun sesak masih tetap sama. Hasil pemeriksaan fisik edema kedua tungkai membaik. Hasil 
laboratorium didapatkan leukosit masih tinggi 11.680, SGOT/SGPT terdapat penurunan menjadi 137/312 U/L. Evaluasi foto toraks didapatkan hasil pengurangan efusi pleura yang cukup signifikan sisi kiri, serta efusi pleura minimal sisi kanan, parenkim paru kanan dan kiri semakin jelas dan fibrosis pada 1/3 tengah paru kanan dan kiri semakin jelas, garis kolaps semakin berkurang. Pasien direncanakan untuk desentisasi isoniazid dan rifampisin jika LFT kembali normal, fisioterapi dada, antibiotik sefoperazon-sulbactam dihentikan terkait pemberian lebih dari 10 hari dan pasien hanya melanjutkan antibiotik adjuvant TB.

Pada tanggal 11 April 2018 kondisi pasien kembali memburuk, sesak semakin berat, nyeri dada kanan dan kiri memberat, edema tungkai kembali muncul, cairan pleura nampak semakin keruh dan kental serta didapatkan pus tepat pada ujung kedua sambungan WSD. Hasil evaluasi leukosit meningkat menjadi 14.200, SGOT/SGPT turun menjadi 73/160 U/L, procalcitonin 0,51 ng/ml, Anti Hepatitis C Virus (HCV) non reaktif, albumin turun 2,6 gr/dl. Hasil AGD $(\mathrm{pH}$ 7,34, $\mathrm{pCO}_{2} 56 \mathrm{mmHg}, \mathrm{pO}_{2} 34 \mathrm{mmHg}, \mathrm{HCO}_{3} 30,2$

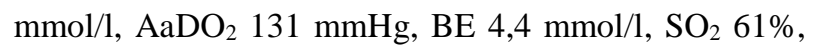
$\mathrm{FiO}_{2} 33 \%$ ) didapatkan alkalosis respiratorik dengan hipoksemia sedang. Hasil USG abdomen didapatkan penurunan intensitas echo parenkim hepar dengan echo texture yang heterogen, dapat merupakan gambaran hepatitis akut serta efusi pleura kiri. Evaluasi foto toraks didapatkan paru kiri semakin mengembang dan garis kolaps berkurang banyak, corakan fibrosis yang semakin jelas di 1/3 tengah paru kanan dan kiri serta penambahan infiltrat di kedua lapang paru. Pasien dilakukan pemeriksaan kultur dan uji sensitifitas cairan pleura dan dilanjutkan instilasi cairan pleura dengan tujuan diagnostik untuk pengambilan sampel oleh karena spesimen BAL dari bronkoskopi tidak dapat dilakukan, selain itu instilasi juga untuk mengencerkan cairan empiema sehingga mudah terjadi drainase. Instilasi menggunakan ciprofloxacin menunjukkan cairan pleura nampak keruh kental bercampur nanah. Pemeriksaan spectrofotometri silika cairan pleura didapatkan kandungan silika pleura kanan 11,15 $\mathrm{ppmSiO}_{2}$, kandungan silika pleura kiri 11,04 $\mathrm{ppmSiO}_{2}$. Pasien didiagnosis sesak napas, gagal napas tipe II, pyopneumotoraks spontan sekunder bilateral, silikosis, HAP, hipokalemia membaik, transaminitis non spesifik. Pasien kembali diberikan antibiotik spektrum luas sesuai uji sensitifitas awal yakni meropenem 1 gram tiap 8 jam intravena.

Pada tanggal 15 April 2018 selang WSD sisi kiri terlepas secara tiba-tiba, pasien merasakan sesak memberat. Sementara dilakukan observasi 24 jam dan foto toraks ulang, jika pneumotoraks bertambah maka selang WSD akan dipasang kembali, sementara luka WSD kiri ditutup. Foto toraks pasien hari ke-34 perawatan, tampak adanya penambahan infiltrat yang luas di seluruh paru kiri. Antibiotik meropenem 1 gram tiap 8 jam intravena tetap dilanjutkan sambil menunggu hasil kultur dan uji sensitifitas dari cairan pleura. Pasien diberikan oksigenasi maksimal dengan NRM 10 lpm, injeksi dexamethasone $0,5 \mathrm{mg}$ tiap 8 jam intravena untuk kecurigaan sepsis dengan gagal napas yang memberat. Kondisi pasien beberapa jam semakin memburuk, sesak semakin hebat, tekanan darah semakin menurun di bawah $80 \mathrm{mmHg}$. Hasil evaluasi AGD didapatkan $\left(\mathrm{pH} 7,26, \mathrm{pCO}_{2} 79 \mathrm{mmHg}, \mathrm{pO}_{2} 88 \mathrm{mmHg}\right.$, $\mathrm{HCO}_{3} 35,5 \mathrm{mmol} / \mathrm{l}, \mathrm{TCO}_{2} 37,9 \mathrm{mmol} / \mathrm{l}, \mathrm{BE} 8,4 \mathrm{mmol} / \mathrm{l}$, $\mathrm{SO}_{2} 95 \%$ ) asidosis respiratorik kompensasi alkalosis metabolik dengan hipoksemia berat. Kesadaran dan tekanan darah pasien semakin turun, kemudian pasien mengalami apnu dan nadi tidak teraba, pasien dinyatakan meninggal pada pukul 14.30 setelah Resusitasi Jantung Paru (RJP) 6 siklus dengan sebab kematian gagal napas tipe II yang diperberat oleh HAP.

Pada akhirnya pasien didiagnosis dengan gagal napas tipe II, pyopneumotoraks spontan sekunder bilateral, silikosis, HAP, hipokalemia membaik, transaminitis non spesifik.

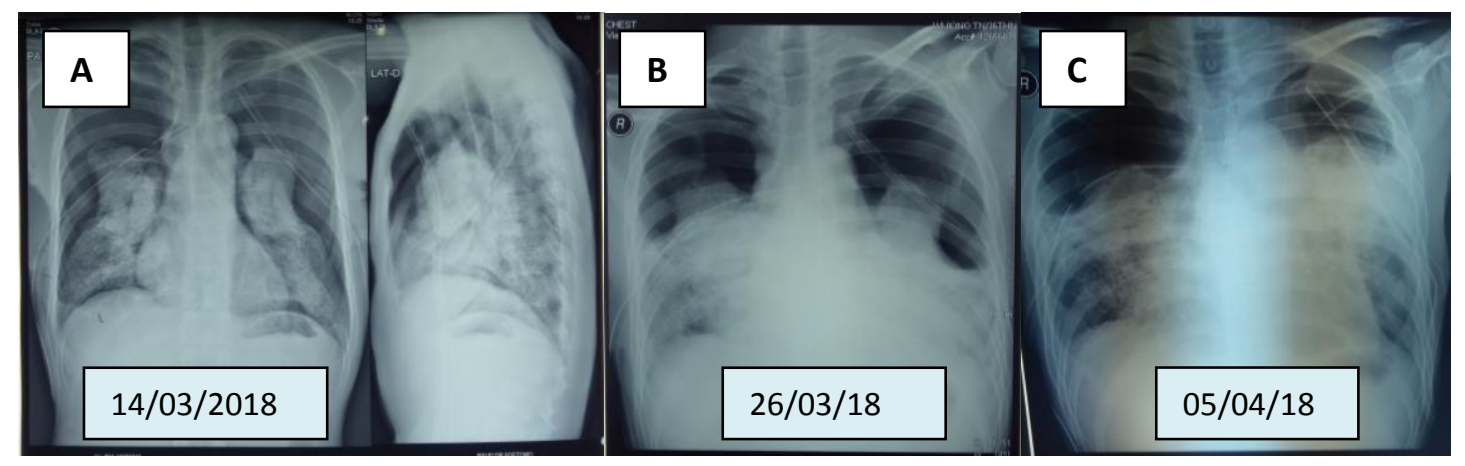

Gambar 2. A. Foto toraks pasien setelah 3 hari perawatan dan post pemasangan WSD di kedua sisi paru. Kedua paru masih tampak kolaps.

B. Foto toraks pasien setelah hari ke-15 perawatan, nampak paru kanan dan kiri mulai mengembang, terdapat penambahan efusi pleura sisi kanan serta opasitas paru kanan-kiri semakin jelas.

C. Foto toraks pasien hari ke-24 perawatan, paru tampak semakin jelas mengembang, opasitas jaringan fibrosis lobus medius paru kanan dan kiri semakin jelas seiring dengan penambahan pengembangan paru. 


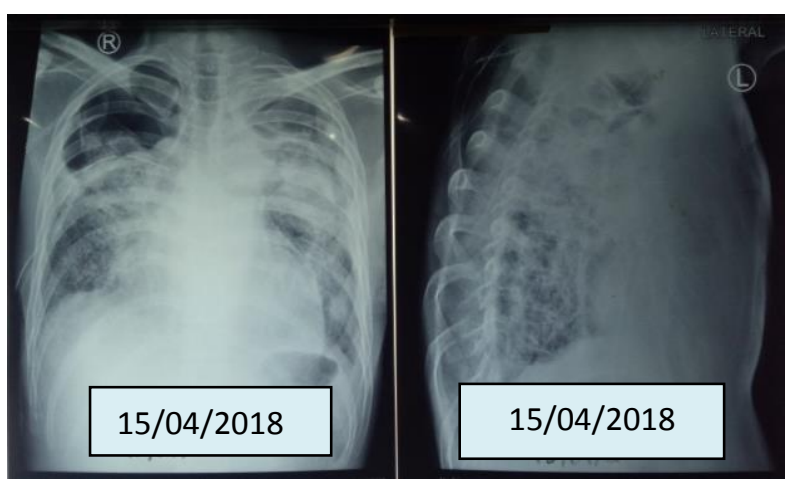

Gambar 3. Foto toraks pasien hari ke-34 perawatan, paru nampak semakin memburuk, terdapat penambahan infiltrat hingga seluruh paru kiri. Fibrosis paru kanan dan kiri tampak semakin jelas.

\section{PEMBAHASAN}

Faktor yang mempengaruhi terjadinya silikosis bergantung pada interaksi 3 komponen, yakni host, agent, dan lingkungan. Faktor agen yang berpengaruh adalah sifat fisika dan kimia partikel yang dalam kasus ini adalah silika. Faktor host adalah pertahanan paru, kondisi yang didapat, anatomi dan fisiologi paru, status imun, umur, ras, gender, status gizi, kebiasaan merokok, kebiasaan penggunaan APD (alat pelindung diri). Sementara faktor lingkungan yang mendukung adalah arah angin, suhu, sistem ventilasi, kelembaban.

Silika dapat ditemukan pada pasir, batu, dan biji besi mineral silika memiliki ukuran $<1 \mu$ m yang tergolong dalam debu respirable yang dapat mencapai alveoli. ${ }^{1}$ Permukaan partikel silika memicu reaksi radikal yang mampu merusak membran sel dan inaktifasi protein sel. ${ }^{1}$ Adapun jenis pekerjaan yang berisiko terpajan silika adalah: tambang logam dan batu bara, industri keramik, pemotongan batu, penggalian terowongan, penuangan besi, baja, pembuatan gigi enamel, pabrik semen, pekerja sandblasting, pengeboran, tunneling, penggilingan tepung silika, dan pembuatan keramik. ${ }^{1}$ Pada pasien ini faktor host yang mendukung adalah gender laki-laki, usia produktif, dan termasuk pekerja keras serta kebiasaan menggunakan APD yang kurang. ${ }^{2}$ Pasien selama 4 tahun sebelumnya sangat jarang menggunakan masker selama bekerja, dan baru menyadari untuk menggunakan rutin selama 3 tahun terakhir. Pasien tergolong dengan gizi kurang dengan BMI $16 \mathrm{~kg} / \mathrm{m}^{2}$. Faktor lingkungan yang mendukung pada pasien adalah tempat kerja pasien berada dalam kawasan yang mayoritas adalah pengrajin batu kali, bekerja dalam ruangan dengan ventilasi kurang, serta kelembaban cukup.

Patogenesis silikosis terutama terjadi pada interaksi antara sel-sel paru dengan partikel silika yang terinhalasi serta respons sekunder yang dicetuskan oleh interaksi tersebut. Bagian permukaan partikel silika berinteraksi dengan makrofag alveoli, limfosit, dan neutrofil yang menimbulkan inflamasi, proliferasi fibroblast, dan deposit bahan-bahan matriks jaringan ikat dalam jumlah yang besar. ${ }^{6}$ Partikel yang ditimbun di alveoli semula terletak pada fagosom, tetapi karena efek toksik silika maka fagosom hancur dan partikel silika terletak bebas dalam sitoplasma. Enzim lisosom dilepaskan dari fagosom yang hancur sehingga menyebabkan makrofag cepat mati dan isinya, termasuk partikel silika, terlepas ke jaringan ekstraseluler. Makrofag akan berkumpul lebih banyak setelah memakan debu silika yang kemudian akan terbunuh pula. Efek sitotoksik silika adalah faktor penting dalam pembentukan jaringan fibrosis. Kematian makrofag akan merangsang pembentukan kolagen oleh fibroblast di jaringan sekitarnya sehingga terbentuk nodul yang mengandung silika bebas di jaringan interstisial dekat bronkiolus. ${ }^{7}$ Hasil pemeriksaan foto toraks pada pasien ini didapatkan fibrosis luas yang tampak setelah parenkim paru mulai mengembang. Fibrosis ini diduga dari proses inflamasi yang kronis sebagai respon interaksi antara sel-sel paru dan partikel silika.

Pneumotoraks spontan sekunder adalah salah satu komplikasi silikosis pada pleura. Pneumotoraks spontan sering berhubungan dengan silikosis kronis dengan fibrosis masif progresif. Kasus pneumotoraks spontan sekunder sering terjadi unilateral, dan jarang terjadi bilateral. Beberapa kasus pneumotoraks bilateral dilaporkan pada silikosis terakselerasi. Pneumotoraks spontan sekunder dapat juga terjadi pada silikosis akut yang disertai bula. ${ }^{8}$ Pajanan silika terhadap paru menghasilkan produk inflamasi yang menyebabkan jaringan fiber yang elastik pada dinding alveoli yang kemudian membentuk bleb. Fibrosis masif pada jaringan paru menghasilkan astiff non distensible dengan peningkatan elastic recoil. Pneumotoraks spontan sekunder dapat terjadi disebabkan oleh ruptur pada bula dan dapat disertai peningkatan elastic recoil pada jaringan paru. Pneumotoraks merupakan komplikasi fibrosis paru difus dan penyakit bulosa. ${ }^{8}$ Hal ini sering terjadi pada silikosis terakselerasi dan silikosis akut, di mana hal tersebut dapat menyebabkan komplikasi fatal. ${ }^{7}$ Pasien ini mengalami pneumotoraks spontan sekunder bilateral yang diduga diakibatkan oleh silikosis terakselerasi.

Kristal silika yang berukuran kurang dari $1 \mu \mathrm{m}$ diyakini paling patogen. Kristal silika yang masuk ke dalam paru kemudian menyebabkan retensi partikel silika pada lobus atas paru. Kontak langsung jaringan dengan partikel silika menyebabkan ketidakseimbangan antara produk respons inflamasi yang kemudian mempengaruhi elastisitas dinding alveolar serta pembentukan bleb pada alveoli di lobus atas, sehingga terjadi kerusakan pada alveoli dan disfungsi tipe II sel, sehingga paru tidak dapat mengembang. ${ }^{8}$ kemungkinan disebabkan oleh ruptur bleb akibat inflamasi silika 
yang dipicu oleh batuk, dalam hal ini terjadi peningkatan tekanan alveolar yang melebihi tekanan interstisial paru dan menyebabkan udara dari alveoli berpindah ke rongga interstisial kemudian menuju hilus dan menyebabkan pneumomediastinum, dan kemudian udara akan berpindah melalui pleura parietalis pars mediastinal ke rongga pleura sehingga menimbulkan pneumotoraks. $^{9}$

Hubungan antara silikosis dan TB telah dipelajari sejak awal abad ke-20. Risiko berkembang menjadi TB paru dilaporkan 2,8-39 kali lebih tinggi pada pasien dengan silikosis daripada pasien tanpa silikosis. ${ }^{10}$ Brasil memiliki prevalensi $52 \%$ TB paru dalam bentuk fibrosis masif progresif, baru-baru ini dilaporkan pada pasien dengan silikosis. ${ }^{11}$ Studi literatur internasional telah menunjukkan bahwa silikosis akut dan silikosis terakselerasi memiliki insiden tertinggi. ${ }^{12}$

Mekanisme yang mungkin menyebabkan peningkatan kerentanan penderita silikosis terhadap TB adalah partikel silika yang tertimbun di alveoli akan dimakan oleh makrofag, tetapi karena efek toksik silika maka makrofag cepat mati dan partikel silika akan terlepas ke jaringan ekstraseluler. ${ }^{12}$ Partikel silika akan dimakan oleh makrofag. Partikel silika akan dimakan oleh makrofag lain yang kemudian terbunuh pula. Silika dengan dosis subletal juga mengganggu kesanggupan makrofag untuk menghambat pertumbuhan kuman TB karena makrofag adalah faktor utama dalam membuat daya tahan terhadap TB, sehingga alasan meningkatnya kerentanan penderita silikosis terhadap TB menjadi jelas. ${ }^{13}$ Pasien dicurigai TB paru, meskipun GeneXpert sputum dan smear sputum BTA negatif, namun secara klinis dan radiologis mendukung adanya TB paru, yakni adanya klinis batuk lama dan gambaran fibroinfiltrat kedua lapang paru. Pasien akhirnya diberikan adjuvant OAT sambil menilai responnya hingga 2 minggu berikutnya. Namun, kondisi pasien memburuk hingga meninggal sebelum 2 minggu pengobatan.

Berdasarkan dosis dan jangka waktu sejak terjadinya pajanan, lesi silikosis diklasifikasikan menjadi 3, yaitu: ${ }^{8}$ (1) Silikosis Kronis: Silikosis kronik adalah bentuk yang paling sering ditemukan, yang terjadi bertahun-tahun, selama lebih dari 15 tahun setelah terpajan debu silika dengan tingkat pajanan relatif rendah. Biasanya tidak ditemukan gejala atau kelainan pada pemeriksaan fisik; (2) Silikosis Terakselerasi: Silikosis terakselerasi terjadi karena pajanan debu silika dalam jumlah besar namun dalam jangka waktu antara 5-10 tahun. Pajanan silika dengan konsentrasi tinggi selama waktu yang relatif singkat dalam beberapa tahun menghasilkan bentuk yang lebih progresif; (3) Silikosis Akut: Silikosis akut adalah bentuk silikosis yang paling jarang ditemukan. Silikosis akut terjadi karena pajanan debu silika berat dalam jumlah yang sangat besar dalam waktu pajanan mungkin bervariasi dari beberapa minggu sampai 4 atau 5 tahun. Pada kasus ini, pasien menderita silikosis terakselerasi karena pajanan debu silika antara 5-10 tahun, dengan tingkat pajanan yang tinggi disertai dengan gejala klinis keluhan batuk berdahak sejak 4 bulan sebelum dirawat, dan terjadi komplikasi berupa TB yang disebut sebagai silikotuberkulosis dengan penyulit pneumotoraks spontan sekunder, di mana komplikasi inilah yang membuat penderita datang berobat ke RS. Pasien ini tergolong dalam silikosis terakselerasi, di mana diketahui pajanannya selama 7 tahun namun dampaknya cukup difus dengan gambaran Progressive Massive Fibrosis (PMF) yang jelas dan mengenai kedua lapang paru serta kadar silika sudah mencapai ke jaringan pleura, dengan nilai yang cukup tinggi.

Transport partikel silika yang terhirup atau termakan dapat menyebar secara sistemik melalui jalur hemato-limfogen setelah terhirup. Efek sistemik silika adalah silikosis hepatik dan/atau hepatosplenik silikosis, granuloma hepatosplenik silikosis, porfiria hepatik, granuloma cutaneous silika, dan abrasi gusi. Remodeling Ekstra Celular Matriks (ECM) bergantung pada keseimbangan sintesis dan degradasi. Matriks ekstraseluler yang terdegradasi adalah proses bertahap yang kompleks, termasuk di dalamnya adalah Matrix Metalloproteinases (MMPs). Matriks metalloproteinase9 berdampak pada proses skarisasi dan fibrosis pada miokard, hepar, dan ginjal. Studi sebelumnya mendapatkan bahwa delesi gen MMP-9 menghasilkan pengurangan lesi fibrotik interstitial pada tikus dan menghambat allergen atau cedera paru dan hati yang diinduksi oleh fibrosis. ${ }^{10-15}$ Gambaran morfologis kelainan ini bergantung pada luasnya agregasi makrofag, kejadian fibrogenesis, dan perkembangan dari nekrosis atau kerusakan matriks ekstraseluler, yang diduga disebabkan oleh pelepasan enzim lisosom dari makrofag. ${ }^{4}$

Studi Zawila N. dkk menemukan bahwa terdapat gangguan fungsi hati yang signifikan pada pasien yang terpajan debu silika jika dibandingkan dengan kontrol. Lebih dari setengah subjek yang terpajan silika terjadi abnormalitas SGOT dan gamma glutamyl transpeptidase (GGT) dan hampir 20\% mengalami abnormalitas SGPT dan alkaline phosphatase (ALP). Selain itu terdapat penurunan albumin serum secara signifikan pada pasien dengan pajanan silika. ${ }^{16}$

Studi eksperimental terhadap tikus yang terpajan silika berhubungan dengan perkembangan awal dan lanjut proses destruksi fibrosis parenkim hepar dan penekanan regenerasi perbaikan seluler dan intra-seluler. ${ }^{17}$ Studi sebelumnya mengungkapkan beberapa mekanisme yang memungkinkan dampak pajanan silika terhadap hepar, yakni: gangguan imun, remodeling ECM, jalur oksidatif/inflamasi, dan teori transisi epitel mesenkim. ${ }^{18-}$ 20 
Perubahan aktifitas MMPs dengan adanya ekspresi berlebih dari enzim atau inhibitornya dapat berdampak terhadap remodeling matriks paru. Gelatinase A (MMP-2) dan B (MMP-9) diregulasi aktif saat awal terjadi silikosis pada parenkim paru tikus coba, kondisi ini menyebabkan kerusakan membran basalis dan berperan penting terhadap kejadian lesi paru yang meningkatkan kejadian fibrosis. Penurunan matriks hepar yang normal berperan terhadap patogenesis kelainan hepar, khususnya pada tahap awal respons cedera hepar. ${ }^{21}$ Sebagai contoh, MMPs dan tissue inhibitors (TIMPS) berhubungan dengan perkembangan sirosis hati, kerusakan toksik hati, dan aktifitas inflamasi kronis hepatitis kronis. MMP-9 berperan penting terhadap perkembangan cedera organ karena materi ini mampu merusak kolagen tipe IV (membran basal) dan karena keterlibatannya di tahap awal remodeling jaringan yang merupakan karakteristik penyakit hati kronis. Pasien silikosis didapatkan peningkatan MMP-9 yang berdampak pada aktifitas inflamasi hati dan kerusakan hati. ${ }^{22}$ Pada pasien ini dijumpai gangguan fungsi hati ditandai dengan peningkatan SGOT, SGPT, hingga ratusan serta adanya penurunan kadar albumin yang tidak membaik meski dengan pemberian albumin.

Diagnosis silikosis ditegakkan berdasarkan riwayat pekerjaan dengan pajanan silika, lamanya pajanan silika, serta adanya temuan radiografik pada foto toraks menentukan jenis silikosis. $^{3}$ Temuan radiografik pada foto toraks silikosis dibagi menjadi dua, yaitu simple silikosis dan PMF (progressive massif fibrosis). Gambaran radiologis pada simple silikosis adalah adanya opasitas berbentuk nodul, berukuran kecil (diameter $<10 \mathrm{~mm}$ ), kadang berbentuk irregular pada bagian atas paru. Sedangkan gambaran radiologis pada PMF yaitu adanya opasitas berbentuk nodul, berukuran lebih besar (diameter > $10 \mathrm{~mm}$ ), terletak pada paru bagian atas sampai tengah. ${ }^{23}$ Pada pasien ini terdapat riwayat pajanan silika, yakni pekerjaan sebagai pengrajin batu kali sejak 7 tahun dan tanpa penggunaan masker selama 4 tahun. Pada radiologi nampak gambaran PMF di mana opasitas berbentuk nodul yang cukup luas dibagian lobus medius paru kanan dan lobus inferior-superior paru kiri yang cukup difus.

Opasitas berbentuk cabang, yang mewakili fibrosis peribronkiolar, merupakan tanda-tanda awal silikosis. Perubahan pleura juga telah diamati pada silikosis, yang utama adalah efusi pleura (12\%), penebalan pleura (58\%), dan invaginasi pleura, termasuk atelektasis yang ditemukan pada beberapa kasus fibrosis masif progresif pada silikosis kronis. ${ }^{24}$ Pada pasien ini dijumpai adanya atelektasis paru kanan kiri, efusi pleura kanan kiri, serta adanya fibrosis peribronkial.

Temuan radiologi silikosis kronis tanpa komplikasi adalah perselubungan berbentuk lingkaran yang halus pada lapangan paru, biasanya menyerupai tipe "r". Ukuran perselubungan kurang dari 10mm. Perselubungan simetris pada kedua paru dan terletak pada paru lobus atas, kadang-kadang terjadi kalsifikasi seperti mikrolitiasis. Diawali dengan pembesaran kelenjar pada hilus terlebih dahulu, kemudian diikuti dengan kelainan pada parenkim paru. Kalsifikasi pada kelenjar getah bening pada hillus seperti "eggshell" hanya terjadi pada $10 \%$ dari kasus tersebut. Walaupun ditemukan hanya pada sebagian kecil kasus, tetapi sangat menyokong diagnosis silikosis. Pada silikosis terakselerasi, gambaran foto toraks mirip dengan silikosis kronis, sedangkan pada silikosis akut, lebih sering ditemukan gambaran difus pada interstisial, dan jarang ditemukan opasitas berbentuk nodul, air bronkogram dapat ditemukan. ${ }^{24}$ Pada pasien ini hasil foto toraks ditemukan gambaran reticulogranular patern di parahiler-paracardial kanan dan kiri yang dapat merupakan interstitial pneumonia.

HRCT dada lebih sensitif dibanding foto toraks untuk melihat silikosis sederhana. Pada silikosis terkomplikasi, CT-scan memberikan hasil lebih jelas (kaviti). Walaupun kaviti pada silikosis dapat terjadi tanpa infeksi mikobakterium, tetapi kemungkinan penyakit ini perlu diperhatikan. ${ }^{25}$ Meskipun sensitifitas HRCT lebih tinggi, hal ini hanya digunakan dalam kasus di mana ada keraguan secara klinis maupun radiologis. ${ }^{24}$ Pada pasien ini, hasil HRCT didapatkan: reticullar pattern dengan konsolidasi di kedua lapang paru disertai kalsifikasi minimal di daerah hilar kanan dan kalsifikasi limfonodi masih mungkin gambaran silikosis, fluidopneumotoraks kiri dan pneumotoraks kanan, limfonodi subcentimeter di upper paratrakea kiri.

Pada kondisi tertentu, diperlukan diagnosis pasti pajanan bahan di lingkungan kerja dengan analisis bahan biologi (sputum, BAL, biopsi transbronkial atau biopsi paru terbuka) untuk melihat debu mineral atau produk metabolismenya. Pemeriksaan BAL membantu menegakkan diagnosis. Pada pemeriksaan BAL, dapat terlihat debu di dalam makrofag, dan jenis debu tersebut kemungkinan dapat diidentifikasi menggunakan mikroskop elektron. Pada silikosis, makrofag yang ditemukan dalam BAL berisi partikel granit yang semakin lama riwayat pajanan terhadap debu granit maka akan semakin banyak ditemukan makrofag tersebut. Selain itu, nodul silikotik dapat ditemukan pada pemeriksaan histopatologi silikosis. ${ }^{26}$ Pada kasus ini pemeriksaan spesimen BAL melalui bronkoskopi tidak memungkinkan dilakukan mengingat kondisi pasien yang tidak stabil.

Keberadaan silika tidak hanya dijumpai pada cairan BAL, dari cairan pleura juga dapat ditemukan, terutama pada silikosis tahap lanjut. Berbagai penyebab kelainan yang melibatkan pleura dapat terjadi, khususnya fibrosis paru lanjut seperti yang telah disebutkan sebelumnya. Meskipun silikosis pleura masih 
jarang terjadi dan kurang jelas literaturnya jika dibandingkan dengan kejadian asbestosis, namun silikosis pada pleura banyak dihubungkan dengan adanya plak pleura, efusi pleura, dan penebalan pleura difus. Kadar silika dalam pleura normalnya adalah nol, dalam kondisi tertentu di mana telah terjadi agregasi makrofag hingga ke pleura, maka kadar silika akan muncul dan meningkat sesuai dosis dan tingkat pajanan. ${ }^{27}$ Pada pasien dilakukan pemeriksaan sampel cairan pleura untuk pemeriksaan spectrophotometer silica, dan didapatkan hasil kandungan silika pleura kanan 11,15 $\mathrm{ppmSiO}_{2}$, kandungan silika pleura kiri $11,04 \mathrm{ppmSiO}_{2}$.

Terdapat 2 studi kasus dan 1 studi retrospektif yang mengevaluasi lebih lanjut efusi pleura dalam upaya membuktikan silikosis dari hasil otopsi. Al-Kasimi melaporkan kasus silikosis paru yang disertai dengan efusi pleura. ${ }^{28}$ Zeren dkk juga melaporkan penampakan silika yang dihubungkan dengan efusi pleura dan pleuritis. $^{29}$

Studi Arakawa dkk menghubungkan secara retrospektif gambaran 110 pasien yang telah diotopsi untuk membuktikan adanya silikosis. Mereka menemukan bahwa efusi pleura terjadi pada $35 \%$ pasien studi, sebanyak $68 \%$ pasien tersebut kemungkinan penyebabnya adalah non silikosis, dan hanya $11 \%$ yang benar-benar berhubungan dengan silikosis setelah menemukan kandungan silika pada cairan pleura. Arakawa dkk menggambarkan beberapa kelainan pleura pada silikosis, seperti penebalan pleura dan PMF yang berhubungan dengan invaginasi pleura. ${ }^{30}$

Biopsi pada jaringan paru akan nampak bentukan silika, sehingga dapat membedakan fibrosis massif progresif akibat silikosis atau kanker paru, TB, dll. ${ }^{3}$ Pasien tidak memungkinkan untuk dilakukan biopsi jaringan paru, mengingat kondisi pasien yang tidak operable.

Penatalaksanaan terpenting adalah pencegahan terjadinya silikosis. Pencegahan dilakukan pada tempat kerja yang mempunyai risiko silikosis, seperti penggunaan air pada beberapa tempat kerja untuk mencegah debu yang beterbangan. Hal yang penting adalah mengontrol kadar debu, sehingga tidak melebihi ambang batas yang direkomendasikan. Ventilasi yang baik di tempat kerja harus ada, agar udara bersih dapat masuk dan debu tidak menumpuk di tempat kerja. Oleh karena itu, penting untuk meningkatkan kewaspadaan terhadap terjadinya silikosis pada pekerja dengan risiko tinggi. ${ }^{17}$ Belum ada obat yang terbukti efektif untuk silikosis. Pengobatan ditujukan pada komplikasi penyakit yang terjadi. Terapi yang dilakukan sama seperti pengobatan obstruksi saluran napas, infeksi, pneumotoraks, hipoksemia, dan gagal napas. Bila penyakit telah menimbulkan gejala, maka diberikan terapi simtomatis seperti pemberian oksigen dan antibiotik apabila terdapat infeksi. ${ }^{17}$

Penelitian terbaru mengungkapkan peranan dari cell-based therapy terhadap silikosis. Dengan keterbatasan terapi intervensi yang efektif terhadap silikosis, terapi berbasis sel memberikan harapan menjanjikan bagi silikosis. Kunci efektivitas terapi ini adalah penurunan kerusakan jaringan akibat proses fibrosis dan inflamasi, mengurangi apoptosis, dan meningkatkan perbaikan dari sel yang rusak. Keuntungannya nampak pada sel poten yang bebas namun memiliki fungsi layaknya endokrin/parakrin (mengekskresikan antiinflamasi, mediator antifibrotik, dan vesikel extraseluler). Lassance dkk menggunakan infus sel mononuclear bone marrow-derived cells (BMDC) pada populasi silikosis dan dievaluasi pengaruhnya dalam dua kali pemberian. Hasilnya menunjukan pengurangan proses inflamasi setelah 30 hari terapi dan terbukti memperbaiki fungsi paru, namun manfaat ini akan berangsur-angsur menghilang selama 60 hari berikutnya. Kemudian lanjutan studi ini pada 2013 menunjukan bahwa penggunaan dosis multiple BMDC mampu mencegah progresifitas penyakit silikosis. Dua kali infus bone marrow cells mampu mengurangi inflamasi (fraksi granuloma dan jumlah total makrofag M1), remodeling paru (kadar TGF-B, deposit kolagen, dan serat elastis), dan apoptosis (caspase level-3 dan jumlah sel apoptosis). ${ }^{31}$

Penelititan tahun 2011 dengan menggunakan keseluruhan dari bone marrow derived mononuclear cells (BMMC) pada tikus menunjukan kemampuan dalam mencegah komponen dari silika yang merangsang kerusakan paru. Infus sistemik dari BMMC mampu mengurangi ekspresi caspase-3, IL-1B, IL-1a dan TGFB. ${ }^{32}$ Lebih jauh, terapi dengan BMMC pada stadium akhir silikosis mampu mengurangi fibrosis paru dan terbukti memperbaiki fungsi paru, namun terapi ini tidak mampu memperbaiki proses inflamasi yang sudah terjadi. ${ }^{33}$

Prognosis penyakit tergantung luas lesi, respons parenkim terhadap silika, banyaknya lesi fibrosis, progresifitas penyakit dan kegagalan organ. ${ }^{1}$ Pada pasien ini hanya dilakukan terapi simptomatis dan paliatif terkait prognosis pasien yang buruk.

\section{KESIMPULAN}

Telah dilaporkan pasien laki-laki 36 tahun dengan silikotuberkulosis dan penyulit pneumotoraks bilateral serta gangguan fungsi hepar (transaminitis non spesifik). Pasien adalah pengrajin batu kali yang diduga memiliki kandungan silika tinggi, dan telah terpajan lama lebih dari 7 tahun dengan minimal APD. Manifestasi klinis yang muncul pada pasien adalah sesak 
napas, batuk, tanda-tanda garis kolaps, serta adanya peningkatan enzim hati. Hasil penunjang HRCT menunjukkan: (1) gambaran reticullar pattern dengan konsolidasi di kedua lapang paru disertai kalsifikasi minimal di daerah hilar kanan dan kalsifikasi limfonodi yang masih mungkin merupakan gambaran silikosis, (2) fluidopneumotoraks kiri dan pneumotoraks kanan, dan (3) limfonodi subcentimeter di upper paratrakea kiri. Respons awal terapi kedua paru nampak mulai mengembang, namun kondisi pasien masih tetap sesak dan semakin lama semakin memberat. Pasien mengalami perburukan fungsi hati disertai dengan infeksi pneumonia (HAP) serta pyopneumotoraks, hingga akhirnya pasien dinyatakan meninggal akibat gagal napas yang mungkin diperberat oleh infeksi. Akhirnya pasien didiagnosis dengan gagal napas tipe II, pyopneumotoraks spontan sekunder bilateral, silikosis, HAP, hipokalemia membaik, transaminitis non spesifik.

\section{DAFTAR PUSTAKA}

1. M.Jusuf Wibisono W, Slamet Hariadi. Buku Ajar Ilmu Penyakit Paru. IPP FK.Unair RSUD Dr. Soetomo, 2010.

2. Barboza CEG, Winter DH, Seiscento M, Santos UDP and Terra Filho M. Tuberculose e Silicose: Epidemiologia, Diagnóstico e Quimioprofilaxia. Jornal Brasileiro de Pneumologia. 2008; 34: 959-66.

3. Mason TH, Stephens PA, Apollonio M and Willis SG. Predicting Potential Responses to Future Climate in an Alpine Ungulate: Interspecific Interactions Exceed Climate Effects. Glob Chang Biol. 2014; 20: 3872-82.

4. Calvert GM, Rice FL, Boiano JM, Sheehy JW and Sanderson WT. Occupational Silica Exposure and Risk of Various Diseases: An Analysis Using Death Certificates from 27 States of the United States. Occupational and Environmental Medicine. 2003; 60: 122-9.

5. Mishra P, Jacob SE, Basu D, Panigrahi MK and Govindaraj V. Bilateral Spontaneous Pneumothorax in Chronic Silicosis: A Case Report. Case Reports in Pathology. 2014; 2014: 561861.

6. David G. Silicosis. In: Hendrick D, Beckett W, Burge PS and Chung A, (Eds.). Occupational Disorders of the Lung. Philadelphia: W.B. Saunders Company, 2002, P. $105-12$.

7. Hinshaw $\mathrm{H}$ and Murray J. Silikosisin Disease of the Chest. In: Murray J, Nadel J, Mason R and Boushey H, (Eds.). Textbook of Respiratory Medicine. 3rd Ed. Philadelphia: W.B. Saunders Company, 1998, P. 716-22.

8. Seaton A. Silicosis. In: Morgan WKC and Seaton A, (Eds.). Occupational Lung Diseases. Philadelphia: W.B. Saunders Company, 1996, P. 250-322.

9. Mohebbi I, Hassani E, Salarilak S and Bahrami AR. Do Bullae and Emphysema Increase Risk of Pneumothorax in Silicosis? Indian J Occup Environ Med. 2007; 11: 108-12.

10. Scabilloni JF, Wang L, Antonini JM, Roberts JR, Castranova V and Mercer RR. Matrix Metalloproteinase Induction in Fibrosis and Fibrotic Nodule Formation due to Silica Inhalation. American Journal of PhysiologyLung Cellular and Molecular Physiology. 2005; 288: L709-L17.
11. Lim DH, Cho JY, Miller M, Mcelwain K, Mcelwain S and Broide DH. Reduced Peribronchial Fibrosis in Allergen-Challenged MMP-9-Deficient Mice. American Journal of Physiology-Lung Cellular and Molecular Physiology. 2006; 291: L265-L71.

12. Gieling RG, Wallace $\mathrm{K}$ and Han Y-P. Interleukin-1 Participates in the Progression from Liver Injury to Fibrosis. Am J Physiol Gastrointest Liver Physiol. 2009; 296: G1324-G31.

13. Mukherjee R, Colbath GP, Justus CD, et al. Spatiotemporal Induction of Matrix Metalloproteinase- 9 Transcription after Discrete Myocardial Injury. Faseb Journal : Official Publication of the Federation of American Societies for Experimental Biology. 2010; 24: 3819-28.

14. World Medical Association Declaration of Helsinki: Ethical Principles for Medical Research Involving Human Subjects. JAMA. 2013; 310: 2191-4.

15. Office IL. Guidelines for the Use of the ILO International Classification of Radiographs of Pneumoconiosis. In: 22 Osahsn, (Ed.). Geneva: International Labour Office, 2011.

16. Zawilla N, Taha F and Ibrahim Y. Liver Functions in Silica-Exposed Workers in Egypt: Possible Role of Matrix Remodeling and Immunological Factors. International Journal of Occupational and Environmental Health. 2014; 20: 146-56.

17. Skurupiy VA, Nadeev AP and Karpov MA. Evaluation of Destructive and Reparative Processes in the Liver in Experimental Chronic Granulomatosis of Mixed (Silicotic and Tuberculous) Etiology. Bulletin of Experimental Biology and Medicine. 2010; 149: 685-8.

18. Pernis B. Silica and the Immune System. Acta BioMedica : Atenei Parmensis. 2005; 76 Suppl 2: 38-44.

19. Huang X. Iron, Oxidative Stress, and Cell Signaling in the Pathogeneses of Coal Workers' Pneumoconiosis, Silicosis, and Asbestosis. Am J Biomed Sci Am J Biomed Sci. 2011; 3: 95-106.

20. Van Berlo D, Knaapen AM, Van Schooten FJ, Schins RP and Albrecht C. NF-kappaB Dependent and Independent Mechanisms of Quartz-Induced Proinflammatory Activation of Lung Epithelial Cells. Particle and Fibre Toxicology. 2010; 7: 13.

21. Raghu G, Striker LJ, Hudson LD and Striker GE. Extracellular Matrix in Normal and Fibrotic Human Lungs. The American Review of Respiratory Disease. 1985; 131: 281-9.

22. Arthur MJP. Fibrogenesis II. Metalloproteinases and Their Inhibitors in Liver Fibrosis. American Journal of Physiology-Gastrointestinal and Liver Physiology. 2000; 279: G245-G9.

23. Banks D. The Health Effects of Silika and Coal Dust Exposure. In: King S, (Ed.). Interstisial Lung Disease. 5th Ed. Raleigh: pmph USA, 2011, P. 499-541.

24. Antao VC, Pinheiro GA, Terra-Filho M, Kavakama J and Müller NL. High-Resolution CT in Silicosis: Correlation with Radiographic Findings and Functional Impairment. Journal of Computer Assisted Tomography. 2005; 29: 350-6.

25. Editor T. Bunga Rampai Penyakit Paru Kerja dan Lingkungan/Tim Editor, Mukhtar Ihsan, Faisal Yunus, Agus Dwi Susanto . - - Seri.1. FKUI, 2009.

26. Rees D and Murray J. Silica, Silicosis and Tuberculosis. The International Journal of Tuberculosis and Lung Disease : The Official Journal of the International Union against Tuberculosis and Lung Disease. 2007; 11: 47484. 
27. Health NIFOSA. Health Effects of Occupational Exposure to Respirable Crystalline Silica. In: Services Dohah, (Ed.). Ohio: National Institute for Occupational Safety and Health, 2002.

28. Al-Kassimi FA. Pleural Effusion in Silicosis of the Lung. British Journal of Industrial Medicine. 1992; 49: 448-50.

29. Zeren EH, Colby TV and Roggli VL. Silica-Induced Pleural Disease: An Unusual Case Mimicking Malignant Mesothelioma. Chest. 1997; 112: 1436-8.

30. Arakawa H, Honma K, Saito Y, et al. Pleural Disease in Silicosis: Pleural Thickening, Effusion, and Invagination. Radiology. 2005; 236: 685-93.
31. Lassance RM, Prota LF, Maron-Gutierrez T, et al. Intratracheal Instillation of Bone Marrow-Derived Cell in an Experimental Model of Silicosis. Respiratory Physiology \& Neurobiology. 2009; 169: 227-33.

32. Maron-Gutierrez T, Castiglione RC, Xisto DG, et al. Bone Marrow-Derived Mononuclear Cell Therapy Attenuates Silica-Induced Lung Fibrosis. The European Respiratory Journal. 2011; 37: 1217-25.

33. Lopes-Pacheco M, Ventura TG, De Oliveira HDA, et al. Infusion of Bone Marrow Mononuclear Cells Reduces Lung Fibrosis but Not Inflammation in the Late Stages of Murine Silicosis. Plos One. 2014; 9: E109982. 